\title{
PREVALENSI GANGGUAN PERILAKU PADA WANITA PEKERJA SEKS USIA REMAJA DI KOTA MANADO
}

\author{
Mercy Juliana Jacqualine \\ Theresia. M.D Kaunang \\ Herdy Munayang
}

Bagian Psikiatri Fakultas Kedokteran Universitas Sam Ratulangi Manado

\begin{abstract}
Introduction: Behavioral disorders are mental disorder which are often overlooked by many people. Whereas as a result of behavioral disorders would very dangerous if left unchecked. Adolescence is an particularly vulnerable age for developing conduct disorder. Adolescents who have behavioral disorders have tendency of engage in activities that deviate including againts parents, lying and stealing. These gestures are the types of behavioral disorders and impaired conduction opposed. Perversity is what that associated with behavioral disorders, especially for teenagers who work as female sex workers.

Methods: This research is a descriptive cross-sectional study design. By using research instruments informed consent, mini-kid, and kuesioner. The results will be processed by univariate analysis. Fallowed by qualitative research by depth interviews with the subject.

Result: Result found as many as $70 \%$ had a history of opposing interference, $36.6 \%$ had a history of mild behavioral disorders, and $30 \%$ had experienced a history of conduct disorder being.
\end{abstract}

Key Words: Behavioral disturbances, interruption againts, adolescent, Mini-Kid.

\begin{abstract}
Abstrak
Pendahuluan: Gangguan perilaku merupakan salah satu gangguan mental yang seringkali diabaikan oleh banyak orang. Padahal akibat dari gangguan perilaku akan sangat berbahaya jika terus dibiarkan. Usia remaja merupakan usia yang sangat rentan untuk terkena gangguan perilaku. Remaja yang mengalami gangguan perilaku memiliki kecendrungan untuk melakukan kegiatan yang menyimpang termasuk melawan orang tua, berbohong dan mencuri. Sikap-sikap tersebut merupakan jenis gangguan perilaku konduksi dan gangguan menentang. Perbuatan menyimpang inilah yang dikaitkan dengan gangguan perilaku terutama bagi remaja yang berprofesi sebagai wanita pekerja seks.

Metode: Penelitian ini bersifat deskriptif dengan desain penelitian cross-sectional. Dengan mengunakan instrumen penelitian mini-kid dan kuesioner. Hasil penelitian akan diolah dengan analisis univariat. Dilanjutkan dengan penelitian kualitaif berupa wawancara mendalam dengan 2 subjek, yang hasil penelitiannya akan disajikan dalam bentuk naratif.

Hasil: Didapati sebanyak 70\% WPS memiliki riwayat gangguan menentang, 36,6\% mengalami riwayat gangguan tingkah laku ringan, dan 30\% pernah mengalami riwayat gangguan tingkah laku sedang.
\end{abstract}

Kata Kunci: Gangguan tingkah laku, gangguan menentang, remaja, Mini-KID 


\section{PENDAHULUAN}

Prostitusi atau pelacuran mempunyai sejarah yang panjang dalam peradaban manusia. Prostitusi telah berada ditengah-tengah masyarakat sejak berabadabad silam. Hal ini baik yang terjadi di Indonesia maupun di negara-negara lain. Sejak adanya kehidupan manusia telah di atur oleh norma-norma perkawinan, sudah ada pelacuran sebagai salah satu penyimpangan dari pada norma-norma perkawinan. Sebenarnya masalah prostitusi ini merupakan masalah yang sangat rawan dan sangat kompleks. Oleh sebab itu kegiatan ini memerlukan perhatian dan penanganan yang serius dari berbagai aspek. ${ }^{1}$

Di Indonesia kegiatan prostitusi telah dianggap sebagai penyakit sosial, karena kegiatan prostistusi ini dapat menimbulkan berbagai akibat yang berbahaya bagi wanita yang bersangkutan, keluarganya maupun masyarakat disekitarnya. Gejala sosial yang dapat timbul dari kegiatan ini antara lain timbulnya penyakit kelamin, berbagai kriminalitas, bahkan timbulnya masalah kejiwaan yang dapat meresahkan masyarakat sekitar. ${ }^{3}$

Masalah kejiwaan yang dapat timbul dapat berupa dampak psikologis dalam hal yang negatif atau kurang baik. Salah satu masalah kejiwaan yang dapat timbul dari dampak negatif psikologis akibat prostitusi adalah gangguan perilaku. $^{4}$

Gangguan perilaku bisa muncul pada hampir semua tahapan usia dengan karakteristik khasnya masing-masing, dari taraf yang paling ringan hingga yang berat. Gangguan perilaku adalah pola perilaku signifikan secara klinis yang terjadi pada individu, yang dikaitkan dengan adanya distress atau kegagalan atau adanya peningkatan resiko kematian, kesakitan, ketidakmampuan, atau hilangnya kebebasan. Biasanya kondisi ini berpengaruh pada kemampuan individu untuk beradaptasi dalam berbagai aspek di dalam kehidupannya. ${ }^{5}$

Gangguan perilaku sendiri secara umum biasanya timbul pada seseorang dalam usia anak-anak maupun remaja. Gangguan ini sering terjadi pada seseorang anak remaja akibat suatu perasaan gagal, perasaan tidak mampu, dan juga kurangnya kebebasan. Hal ini sering didapati pada anak-anak yang berjenis kelamin perempuan. ${ }^{5}$

Pada umumnya anak-anak maupun remaja wanita yang dibesarkan dalam adat timur, memiliki sifat atau karakter yang khas. Biasanya remaja-remaja wanita pada adat timur, sangat dijaga didalam keluarga, dalam hal kebebasan. Kecendrungan remaja wanita di timur tidak di ijinkan untuk bergaul terlalu berlebihan, karena orang tua mereka ingin menjaga nama baik keluarga. ${ }^{6}$

Apabila telah terjadi sesuatu yang membuat nama baik kelurga tercoreng, maka remaja wanita tersebut akan menerima banyak sekali ganjaran bahkan cemooh dari orang-orang disekitarnya. Hidup dalam keadaan seperti inilah yang membuat remaja wanita di Indonesia cenderung memiliki sikap-sikap menentang dan menimbulkan gangguan perilaku yang berdampak pada saat mereka dewasa. ${ }^{6}$

Menurut Benjamin Malzberg rasio pekerja seks wanita yang didapati memiliki kecacatan mental ialah 28\%$97 \%$. Hasil rasio yang besar seperti ini telah diukur dan di lihat berdasarkan waktu serta tempat pemeriksaan yang berdasarkan fakta. Benjamin bahkan menambahkan bahwa presentase yang besar terhadap kecacatan mental seperti ini biasanya terdapat pada wanita-wanita yang pada masa remaja mereka cenderung memiliki sikap-sikap menentang. ${ }^{2}$

Wanita pekerja seks adalah seorang perempuan yang menjual dirinya sendiri untuk kepentingan seks dengan beberapa pria secara terus menerus, dan tidak memiliki kesempatan untuk memilih pria 
mana yang menjadi langganannya. Pekerjaan seperti ini tidak hanya terdapat pada wanita dewasa saja. Saat ini sudah banyak sekali anak-anak terutama remaja yang mencoba untuk terjun kedalam pekerjaan ini. ${ }^{3}$

Yang menjadi masalah sekarang adalah bagaimana jika para remaja yang merupakan tulang punggung generasi mendatang ini memilih suatu pekerjaan yang salah? Apa penyebab yang membuat para remaja ini memilih pekerjaan yang salah? Apakah mereka telah mengalami gangguan perilaku sebelumnya sehingga mereka memilih pekerjaan ini?

Profesi sebagai seorang Wanita Pekerja Seks (WPS) atau lebih di kenal dengan Pekerja Seks Komersial (PSK) adalah suatu golongan pekerjaan yang rentan mengalami gangguan perilaku. Pekerjaan seperti ini memiliki banyak dampak negatif yang akan terlihat sesuai dengan seberapa lama pekerjaan ini mereka tekuni. Salah satu dampak negatif yang bisa terlihat ialah terjadinya gangguan mental yang berupa gangguan perilaku. Semakin lama seorang remaja wanita turun ke dalam profesi seperti ini, maka akan semakin besar pula dampak negatif yang terjadi terhadap kejiwaan remaja wanita tersebut. ${ }^{8}$

Jadi tidak hanya oleh karena faktor pada masa kecil saja seorang wanita yang masuk dalam profesi ini akan mengalami gangguan perilaku. Wanita yang tidak memiliki riwayat gangguan perilaku pun dapat mengalami kecacatan mental apbila ia masuk kedalam profesi seperti ini.

Berdasarkan uraian di atas timbul keinginan penulis untuk melakukan penelitian mengenai prevalensi gangguan perilaku pada wanita pekerja seks usia remaja di Kota Manado serta penelitian kualitatif terhadap dua wanita pekerja seks.

\section{METODE PENELITIAN}

Penelitian ini adalah penelitian jenis deskriptif-kuantitatif dengan studi cross-sectional untuk menilai apakah terdapat gangguan perilaku pada 30 wanita pekerja seks remaja dan apakah gangguan perilaku pada wanita pekerja seks remaja tersebut berbeda berdasarkan umur, pendidikan, agama dan status ekonomi.

Kemudian penelitian ini dilanjutkan dengan metode deskriptif kualitatif. Metode Penelitian Kualitatif ialah penelitian yang bersifat deskriptif dan cenderung menggunakan pendekatan induktif, atau lebih jelasnya penelitian kualitatif ialah jenis penelitian yang temuan-temuannya tidak diperoleh melalui prosedur statistik atau bentuk hitungan lainnya. ${ }^{14}$

Penelitian ini dilaksanakan di beberapa tempat prostitusi di Manado selama bulan Oktober hingga November 2013. Sampel penelitian ini diambil dengan metode purposive sampling sebanyak 30 orang. Kriteria inklusi antara lain remaja yang terbukti bekerja sebagai WPS, bersedia diwawancara, kooperatif dan mau mengisi kuesioner. Kriteria eksklusi antara lain memiliki penyakit fisik, memiliki gangguan psikiatrik pada remaja lainnya seperti Gangguan Pemusatan Perhatian yang Hiperaktif yang sudah terdiagnosis oleh dokter.

Definisi operasional Wanita pekerja seks adalah suatu pekerjaan atau profesi dengan melacurkan diri, penjualan diri dengan jalan memperjual belikan badan, kehormatan dan kepribadian kepada banyak orang untuk memuaskan nafsunafsu seks dengan imbalan pembayaran. ${ }^{1}$ Gangguan perilaku adalah istilah klinis yang mengarah pada pengelompokan aksi antisosial persisten pada remaja. ${ }^{5}$ Dalam penelitian ini terdapat 2 jenis kuesioner gangguan perilaku yang akan diberikan kepada responden. Gangguan menentang oppsisional serta gangguan tingkah laku konduksi.

Umur ialah lamanya hidup berdasarkan kartu tanda penduduk. Dalam penelitian ini umur dibagi atas 3 kategori, kategori remaja awal 11-13 tahun, kategori remaja 14-16 tahun, serta kategori remaja akhir atau dewasa muda yaitu 17-21 tahun. 
Pendidikan menurut jenjang pengajaran yang telah diikuti atau sedang dijalani responden melalui pendidikan formal

Agama adalah kepercayaan yang dianut oleh masing-masing individu terhadap Tuhannya. Status ekonomi keluarga adalah suatu keadaan atau kedudukan yang di atur secara sosial pada posisi tertentu dalam struktur masyarakat. Dalam penelitian ini status ekonomi keluarga dibagi 3 yaitu, kategori ekonomi rendah, kategori ekonomi menengah, dan kategori ekonomi atas.

\section{Prosedur Pelaksanaan Penelitian}

Setiap subyek yang memenuhi kriteria inklusi dan eksklusi diminta untuk mengisi inform consent dan mengisi kuesioner penelitian. Pelaksanaan penelitian dimulai dengan pemberian penjelasan mengenai maksud dan tujuan dari penelitian, pengisian kuesioner-Mini Kid, hasil dari kusioner tersebut yaang diberikan kemudian dilihat apakah memiliki nilai tidak ada riwayat gangguan perilaku, gangguan perilaku ringan, sedang berat. Kemudian peneliti mengambil dua subyek yang memiliki riwayat gangguan perilaku yang terbesar untuk dijadikan subyek penelitian kualitatif. Dilakukan wawancara mendalam mengenai kehidupan kedua subyek yang memiliki riwayat gangguan perilaku.

\section{Pengolahan Data}

Data deskriptif diolah menggunakan program SPSS dan data kualitatif diolah menggunakan teknik analisi data oleh Mils dan Hubermen yaitu analisis data kualitatif model air (flow mode). ${ }^{10}$

\section{HASIL}

\section{Karakteristi Reponden}

Berdasarkan kategori umur menunjukkan bahwa semua responden yang didapat memasuki kategori umur 17-21 tahun, yaitu sebanyak 30 orang (100\%). Tidak didapati responden yang berada di bawah umur 17 tahun.

Tabel 1. Karakteristik Responden Berdasarkan Umur

\begin{tabular}{|c|c|c|c|c|c|}
\hline & & Frequency & Percent & Valid Percent & Cumulative Percent \\
\hline \multirow{6}{*}{ Valid } & 17 & 3 & 10,0 & 10,0 & 10,0 \\
\hline & 18 & 5 & 16,7 & 16,7 & 26,7 \\
\hline & 19 & 7 & 23,3 & 23,3 & 50,0 \\
\hline & 20 & 14 & 46,7 & 46,7 & 96,7 \\
\hline & 21 & 1 & 3,3 & 3,3 & 100,0 \\
\hline & Total & 30 & 100,0 & 100,0 & \\
\hline
\end{tabular}


Berdasarkan karakteristik agama menunjukkan bahwa responden terbanyak adalah yang menganut agama Kristen Protestan, yaitu sebanyak 27 orang (90\%).Terdapat 2 orang responden ( $6,7 \%)$ yang menganut agama Islam, dan 1orang responden $(3,3 \%)$ yang meyakini agama Kristen Katolik.

Tabel 2. Karakteristik Responden Berdasarkan Agama

\begin{tabular}{|ll|r|r|r|r|}
\hline & Frequency & Percent & Valid Percent & Cumulative Percent \\
\hline \multirow{4}{*}{ Valid } & kr.protestan & 27 & 90,0 & 90,0 & 90,0 \\
& Islam & 2 & 6,7 & 6,7 & 96,7 \\
& kr.katolik & 1 & 3,3 & 3,3 & 100,0 \\
& Total & 30 & 100,0 & 100,0 & \\
\hline
\end{tabular}

Berdasarkan status ekonomi menunjukkan bahwa responden terbanyak berada pada tingkat status ekonomi menengah, yaitu sebanyak 14 orang $(46,6 \%)$.

Tabel 3. Karakteristik Responden Berdasarkan Status Ekonomi

\begin{tabular}{|c|c|c|c|c|c|}
\hline & & Frequency & Percent & Valid Percent & $\begin{array}{c}\text { Cumulative } \\
\text { Percent }\end{array}$ \\
\hline \multirow{4}{*}{ Valid } & Rendah & 11 & 36,7 & 36,7 & 36,7 \\
\hline & Menengah & 14 & 46,7 & 46,7 & 83,3 \\
\hline & Atas & 5 & 16,7 & 16,7 & 100,0 \\
\hline & Total & 30 & 100,0 & 100,0 & \\
\hline
\end{tabular}

Berdasarkan karakteristik pendidikan menunjukkan bahwa responden yang terbanyak ialah yang berpendidikan SMA sebanyak 25 orang $(83,4 \%)$.

Tabel 4. Karakteristik Responden Berdasarkan Pendidikan

\begin{tabular}{|c|c|c|c|c|c|}
\hline & & Frequency & Percent & Valid Percent & $\begin{array}{c}\text { Cumulative } \\
\text { Percent }\end{array}$ \\
\hline \multirow{4}{*}{ Valid } & SMP & 3 & 10,0 & 10,0 & 10,0 \\
\hline & SMA & 25 & 83,3 & 83,3 & 93,3 \\
\hline & PT & 2 & 6,7 & 6,7 & 100,0 \\
\hline & Total & 30 & 100,0 & 100,0 & \\
\hline
\end{tabular}

Berdasakan prevalensi gangguan menentang tabel menunjukkan prevalensi riwayat gangguan menentang pada responden dengan presentase sebesar 21 orang (70\%). Serta terdapat 7 orang (30\%) yang tidak mengalami gangguan menetang. 
Tabel 5. Karakteristik Responden Berdasarkan Gangguan

\begin{tabular}{|c|r|r|r|r|}
\hline \multicolumn{1}{|c|}{ Menentang } \\
\hline Tidak & Frequency & Percent & Valid Percent & $\begin{array}{c}\text { Cumulative } \\
\text { Percent }\end{array}$ \\
\hline ya3 & 2 & 23,3 & 23,3 & 23,3 \\
ya4 & 3 & 6,7 & 6,7 & 30,0 \\
ya5 & 5 & 10,0 & 10,0 & 40,0 \\
ya6 & 7 & 23,3 & 16,7 & 56,7 \\
ya7 & 4 & 13,3 & 23,3 & 80,0 \\
ya8 & 1 & 3,3 & 13,3 & 93,3 \\
ya9 & 1 & 3,3 & 3,3 & 96,7 \\
Total & 30 & 100,0 & 3,3 & 100,0 \\
\hline
\end{tabular}

Prevalensi menunjukkan bahwa 66,6 persen responden pernah memiliki riwayat gangguan konduksi. Responden terbanyak ialah yang menderita gangguan tingkah laku konduksi ringan, yaitu sebanyak 11 orang (36\%).

Tabel 6. Karakteristik Responden Berdasarkan Tingkat Perilaku Konduksi

\begin{tabular}{|l|r|r|r|r|}
\hline & Frequency & Percent & Valid Percent & $\begin{array}{r}\text { Cumulative } \\
\text { Percent }\end{array}$ \\
\hline gangguan perilaku berat & 1 & 3,3 & 3,3 & 3,3 \\
gangguan perilaku ringan & 10 & 33,3 & 33,3 & 36,7 \\
gangguan perilaku & 7 & 23,3 & 23,3 & 60,0 \\
sedang & 1 & 3,3 & 3,3 & 63,3 \\
Valid & 1 & 3,3 & 3,3 & 66,7 \\
gangguan perilku ringan & 1 & 3,3 & 3,3 & 70,0 \\
tidak gangguan perilaku & 9 & 30,0 & 30,0 & 100,0 \\
tidak gangguan perilaku & 30 & 100,0 & 100,0 & \\
Total & & & \\
\hline
\end{tabular}

\section{PEMBAHASAN}

Berdasarkan hasil penelitian yang dilakukan dengan memberikan kuesioner kepada 30 reponden, menunjukan prevalensi umur terbanyak adalah kelompok umur 17-21 tahun sebanyak 30 orang (100\%), sedangkan untuk kategori umur yang lain, jarang bahkan pada penelitian ini tidak dijumpai prevalensi pada umur dibawah 17 tahun. Hal ini selaras degan penelitian Andin Verasati pada tahun 2013. ${ }^{11}$ 
Penelitian tersebut menyatakan bahwa hampir semua WPS aktif, berada dalam rentang umur 17-20 tahun. Wanita pekerja seksual usia ini memiliki banyak faktor kecenderungan yang dapat membuat mereka mengalami masalah gangguan perilaku. ${ }^{11}$

Selain itu dikatakan pula bahwa remaja yang berusia dibawah 17 tahun cenderung masih memiliki tingkat pengawasan yang tinggi dari orang tua sehingga tidak terlalu mudah untuk turun kedalam pekerjaan seperti ini. ${ }^{11}$

Dari segi agama prevalensi menunjukan bahwa sebagian besar para WPS tersebut beragama Kristen Protestan dengan presentase 90\%, 3,3\% Katolik dan 6,7\% beragama Muslim. Hal ini selaras dengan penelitian yang dilakukan oleh Mariyadi yang menyatakan bahwa, kepercayaan yang paling banyak dianut oleh para WPS tergantung daerah dan tempat mereka bekerja. ${ }^{12}$

Para WPS yang ada pada penelitian ini mayoritas beragama Kristen Protestan dikarenakan daerah Sulawesi Utara mayoritas beragama Kristen, sehingga banyak dari para WPS yang beragama Kristen. Apabila berada di tempat yang mayoritas beragama lain, maka mungkin hasilnya akan berbeda. ${ }^{12}$

Dari 30 orang responden yang ada, prevalensi menunjukan sebanyak 25 orang responden $(83,4 \%)$ memiliki jenjang pendidikan terakhir yaitu SMA, tingkat perguruan tinggi hanya 2 orang $(6,6 \%)$ serta yang berpendidikan terakhir SMP ada 3 orang (10\%). Hal ini menunjukan bahwa hasil penelitian ini di dominasi oleh responden yang jenjang pendidikan terakhir nya ialah SMA.

Hingga saat ini sebagian besar penelitian mengenai Wanita Pekerja Seks mendapati, tingkat pendidikan yang dijalani oleh para wanita ini ialah SMA sebab mereka diindikasikan berada pada status ekonomi yang rendah. Sehingga tingkat pendidikannya hanya sampai pada jenjang SMA. Hasil penelitian yang dilakukan oleh Erlanda Juwita salah satunya. Dalam penelitian nya dinyatakan tingkat pendidikan yang paling banyak telah dilewati oleh para wanita ini ialah SMA. ${ }^{13}$

Pada penelitian ini didapati, prevalensi status ekonomi 14 orang responden (46,6\%) memiliki tingkat sosial ekonomi yang menengah, 11 orang $(36,6 \%)$ rendah serta 5 orang $(16,8 \%)$ memiliki tingkat sosial ekonomi yang tinggi.

Dalam penelitiannya Andin Verasati menyatakan bahwa salah satu faktor yang membuat para wanita pekerja seks ingin bekerja dalam pekerjaan mereka ialah akibat sosial ekonomi yang rendah. Tapi beberapa tahun belakangan hal itu mulai sedikit berubah, akibat dari perkembangan zaman. ${ }^{11}$

Tingkat ekonomi para WPS di zaman ini menunjukan kenaikan yang signifikan. Hal tersebut tidak hanya disebabkan oleh penghasilan mereka melainkan latar belakang keluarga mereka juga. Salah satu alasan seorang wanita masuk menjadi WPS, ialah modeling yaitu meniru teman-temanya. Banyak anak-anak remaja wanita dari latar belakang ekonomi menengah ke atas menjadikan profesi WPS sebagai sebuah trend. ${ }^{11}$

Menurut tabel 4.5 mengenai distribusi responden berdasarkan diagnostik gangguan menentang didapati 21 orang $(70 \%)$ menderita gangguan menentang, dan 7 orang (30\%) tidak mengalami gangguan menetang. Dapat diinterpretasikan bahwa lebih dari setengah jumlah responden memang menderita gangguan menentang. Beberapa diantaranya didapati memang sudah menderita gangguan menentang cukup lama, dan yang lain baru mengetanghui bahwa mereka mengalami gangguan menentang semenjak mereka menjadi wanita pekerja seksual. $^{9}$

Perempuan memiliki angka yang tinggi pada gangguan menentang karena ada beberapa faktor, pertama faktor banyaknya jumlah kaum hawa di dunia dibandingkan laki-laki, kemudian yang 
kedua adalah dalam gangguan menentang mungkin akan lebih sering dialami olah laki-laki sebelum puberitas dan akan menjadi seimbang setelah pubertas. Ada ahli yang mengatkan bahwa perempuan lebih sering diklasifikasikan kepada diagnosis gangguan menentang dibandingkan dengan laki-laki yang biasanya lebih sering didiagnosis gangguan konduksi. ${ }^{9}$

Menurut Tabel 4.6 mengenai distribusi responden berdasarkan diagnostik gangguan tingkah laku sebanyak 10 orang $(33,4 \%)$ tidak menderita gangguan tingkah laku, 11 orang (36,6\%) menderita gangguan tingkah laku ringan dan 9 orang SIMPULAN

Prevalensi umur terbanyak adalah ketegori umur 17-21 tahun dan prevalensi agama responden yang terbanyak adalah Kristen Protestan. Prevalensi pendidikan terkahir yang paling banyak ialah SMA serta prevalensi status ekonomi responden terbanyak ialah status ekonomi menengah.

\section{REFERENSI}

1. Kartono.K. Patologi Sosial jilid 1. Jakarta : Raja Grafindo Persada;2005, hal.208.

2. Benjamin Malzberg.2009. Mental Defect and Prostitution.Journal of the American Medical Association. 103(5):100-1.

3. Irianto.K.Permasalahan

Seksual.Bandung:Yrama Widya;2013.

4. Judithia.A.Wirawan.Teori Motivasi dalam Psikologi Organisasi.Jakarta: PT.Gramedia;1990.

5. Wicks-Nelson.R.Israel.2006. Behavior Disorder of Childhood. New Jersey. Prentice hall.

6. Aulia.Arif.Kehidupan Pekerja Seks Komersial.Studi Kasus Penyebab mengalami gangguan tingkah laku sedang (30\%).

Presentase nilai gangguan perilaku masih relatif lebih sedikit dibandingkan gangguan menentang. Ada beberapa faktor yang bisa dikaitkan dalam jumlah responden yang mengalami gangguan perilaku, dan faktor-faktor itu bisa membentuk suatu perilaku remaja dewasa yang mungkin menyebabkan pembentukan perilku yang salah. Perilku remaja ini biasanya merupakan tanggapan atau reaksi individu sebagai seorang remaja yang akan beranjak dewasa terhadap rangsangan atau lingkungan yang ada disekitarnya. ${ }^{15}$

Ditemukkan prevalensi gangguan perilaku yang diderita oleh responden cukup besar. Dari 30 responen 70\% responden mengalami riwayat gangguan menentang sedangkan $66,6 \%$ responden memiliki riwayat gangguan konduksi.

Perempuan Mnejadi PSK di Pasar Kembang Yogyakarta. Yogyakrta:Fakultas Dakwa BPI;2008, hal.59-71.

7. Anonim.Hubungan Keharmonisan Keluarga Dengan Penalaran Moral pada Remaja Delikuen.Universitas Sumatra Utara.Chapter II.

8. Popoola BI. Ocuupational hazards and copping strategies of sex workers in Southern Western Nigeria.Health Care Women Int.2013;34;139-49.

9. Kaplan HI, Sadock BJ. Sinopsis Psikiatri Jilid II. Dalam : Wiguna I M, editor. Tanggerang : Binarupa Aksara Publisher, 2010: 754-764.

10.Hadi.S.MetedologiResearch II.Yogyakarta: Andi Ofset. 
11.Andin.V.Motivasi WPS dalam melakukan Tes HIV.Jember:Universitas Jember;2013. Hal 67.

12.Maryudi.Persepsi Masyarakat Tentang Prostitusi Liar. Jakarta.2009.

13.Erlanda.Juwita.Studi Kasus Pekerja Seks Komersial di Surabaya. Suarabaya: Universitas Airlangga.

14.Arifudin.Metedologi Penelitian Kualitatif.Bandung:CV.Pustaka Setia;2009. Hal.134.

15.Pervin L.A, Cervone D, John OP.Psikologi Kepribadian.Edisi 9.Jakarta:Kencana;2010:18-19. 